\title{
Presenteeism in multiprofessional team workers in the Adult Intensive Care Unit
}

\author{
Presenteísmo em trabalhadores da equipe multiprofissional de Unidade de Terapia Intensiva Adulta \\ Presentismo en trabajadores del equipo multiprofesional de Unidad de Terapia Intensiva Adulta
}

\section{Andressa Fernanda Silva' \\ ORCID: 0000-0002-8250-2156 \\ Maria Lúcia do Carmo Cruz Robazzi ORCID: 0000-0003-2364-5787 \\ Rita de Cássia de Marchi Barcellos Dalri' ORCID: 0000-0002-6575-5426 \\ Cristiane Aparecida Silveira-Monteiro" ORCID: 0000-0002-8427-7220 \\ Aida Maria Oliveira Cruz Mendes"'I \\ ORCID: 0000-0002-1992-9632 \\ Universidade de São Paulo, Ribeirão Preto College of Nursing Ribeirão Preto, São Paulo, Brazil. "Pontifícia Universidade Católica de Minas Gerais. Poços de Caldas, Minas Gerais, Brazil. "'Escola Superior de Enfermagem de Coimbra. Coimbra, Portugal. \\ How to mention this article: Silva AF, Robazzi MLCC, Dalri RCMB, Silveira-Monteiro CA, Mendes AMOC. Presenteeism in multiprofessional team workers in the Adult Intensive Care Unit. Rev Bras Enferm [Internet]. 2019;72(Suppl 1):96-104. [Thematic Issue: Work and Management in Nursing]. DOI: http://dx.doi.org/10.1590/0034-7167-2017-0779}

Corresponding Author:

Andressa Fernanda Silva E-mail: andressa.fernanda18@hotmail.com

Submission: 11-21-2017

Approval: 03-09-2018

\section{ABSTRACT}

Objective: To analyze the occurrence of presenteeism in multiprofessional team workers of an Adult Intensive Care Unit, relating it to sociodemographic and labor characteristics. Method: It is an analytical cross-sectional qualitative study, which used a questionnaire for sociodemographic data collection, and Stanford Presenteeism Scale(SPS-6) to assess presenteeism. Results: There was predominance of women (75.9\%), nursing workers $(66.7 \%)$, mean age of 39.81 years, and 6 to 10 years $(31.6 \%)$ of experience in the labor market. Regarding presenteeism, $48.7 \%$ presented work impairment and $31.8 \%$ presentedperformance and completion of tasks altered by this phenomenon. Conclusion: Expressive numbers of general presenteeism were identified, with results indicating impairment in completing work. When connecting presenteeism to sociodemographic and labor characteristics, the variables sex, dependent children and absence from work presented values with statistical significance among the studied workers.

Descriptors: Occupational Health;Working Conditions; Health Personnel; Presenteeism; Nurse Practitioners.

\section{RESUMO}

Objetivo: Analisar a ocorrência do presenteísmo em trabalhadores da equipe multiprofissional de uma Unidade de Terapia Intensiva Adulta e relacionar com as características sociodemográficas e laborais. Método: Estudo analítico, transversal e quantitativo, que utilizou para a coleta de dados um questionário para a obtenção dos dados sociodemográficos e a Stanford Presenteeism Scale SPS-6 para avaliar o presenteísmo. Resultados: Predominaram mulheres $(75,9 \%)$, trabalhadoras de enfermagem $(66,7 \%)$, com média de idade de 39,81 anos e com 6 a 10 anos $(31,6 \%)$ de trabalho. Quanto ao presenteísmo, $48,7 \%$ apresentaram comprometimento no trabalho e $31,8 \%$ tiveram a realização e finalização das tarefas alteradas por este fenômeno. Conclusão: Foram identificados números expressivos de presenteísmo geral, com resultados que indicam comprometimento na finalização do trabalho. Relacionando o presenteísmo com as características sociodemográficas e laborais, as variáveis sexo, ter filhos dependentes e ter-se afastado do trabalho apresentaram valores com significância estatística entre os trabalhadores estudados. Descritores: Saúde do Trabalhador; Condições de Trabalho; Pessoal de Saúde; Presenteísmo; Profissionais de Enfermagem.

\section{RESUMEN}

Objetivo: Analizar la ocurrencia del presentismo en trabajadores del equipo multiprofesional de una Unidad de Terapia Intensiva Adulta y relacionar con las características sociodemográficas y laborales. Método: Estudio analítico, transversal y cuantitativo, que utilizó para la recolección de datos un cuestionario para la obtención de los datos sociodemográficos y la Stanford Presenteeism Scale SPS-6 para evaluar el presentismo. Resultados: La mayoría fue de mujeres $(75,9 \%)$, trabajadoras de enfermería $(66,7 \%)$, con una media de edad de 39,81 años y con 6 a 10 años $(31,6 \%)$ de trabajo. Acerca del presentismo, el $48,7 \%$ presentó compromiso en el trabajo, y el 31,8\% tuvo la realización y finalización de las tareas alteradas por este fenómeno. Conclusión: Se identificaron números expresivos de presentismo general, con resultados que indican compromiso en la finalización del trabajo. Al relacionar el presentismo con las características sociodemográficas y laborales, las variables género, tener hijos dependientes y haber se alejado del trabajo presentar on valores consignificación estadística entre los trabajadores estudiados.

Descriptores: Salud Laboral; Condiciones de Trabajo; Personal de Salud; Presentismo; Enfermeras Practicantes. 


\section{INTRODUCTION}

The work in health areas fundamental to the maintenance of human life ${ }^{(1)}$; it consists of taking care of people, which is a complex activity ${ }^{(2)}$. As a result, workers suffer from exhaustion due to organizational, physical and psychic burdens, regardless of professional class. Events arising from work organization, management strategies, autonomy disrespect and power abuse may be predecessors of such exhaustion ${ }^{(3)}$. Besides, workers experience situations in which they have to deal with pain, suffering, and physical, social and emotional malaise ${ }^{(4)}$.

In health care establishments, Intensive Care Units (ICUs) are critical and specialized areas aimed at patients who are in serious need of skilled professional assistance. In these places, there must be human resources, necessary technologies and adequate materials to perform monitoring and therapy of critical patients, offering them specialized and safe assistance ${ }^{(5)}$.To work at the ICU, workers need to have high degree of specialization ${ }^{(6)}$ at a complex work environment that includes behavioral conflicts, such as poor team communication or situations of verbal abuse ${ }^{(7)}$.

Collective cooperation is needed at those places; the severity of patients' conditions imposes need to deal with sophisticated equipment, performing constant clinical evaluations and complex procedures with immediate decisions. The work cannot be performed by a single professional health category; it requires other members as administrative technicians, cleaning workers, among others ${ }^{(8)}$, although there is always predominance of the nursing team.

In addition, the intensification of work daily routine has become a source of physical exhaustion and mental breakdown, which may result in stress ${ }^{(9)}$, since the person frequently goes to work without being able to perform his/her tasks ${ }^{(10)}$. This is the situation that occurs in presenteeism, condition in which the worker goes to work, however not developing his/her labor activities in a productive way, presenting low performance. Decreased productivity may be related to possible physical and mental issues externalized by the person ${ }^{(11)}$, since he/she is present, in spite of his/her deficient health state, but this does not justify his/her absence from work ${ }^{(12)}$. In some situations, this person is not able to satisfactorily perform what is expected from him/her. Dedication, fear of overloading co-workers, lack of payment for leaves or absence, and difficulties for another professional to replace the person are factors that justify the practice of going to work $^{(13)}$.

It can be noted that presenteeism is a complex phenomenon, and it is related to absenteeism, in a way that working even sick - characteristic of presenteeism - becomes a risk factor for the occurrence of absenteeism ${ }^{(12)}$.

This study was motivated by the few investigations which were identified regarding this phenomenon among ICU multiprofessional team.

\section{OBJECTIVE}

To analyze the occurrence of the presenteeism in multiprofessional team workers of an Adult Intensive Care Unit, relating it to sociodemographic and labor characteristics.

\section{METHOD}

\section{Ethical Aspects}

The study was approved by the Research Ethics Committee of the Nursing School of Ribeirão Preto-USP, and the participants were included after agreeing upon participating in the study, reading and signing the Informed Consent Form.

\section{Design, study place and period}

This is an analytical cross-sectional, correlational qualitative study, developed at an Adult Intensive Care Unit (AICU) of a largesized Brazilian hospital, an institution whose work contracts are carried out by means of civil service examination or through its support foundation.

Data collection took place at the AICU between November and December 2016, by the first author of this study, including weekends and holidays, after having obtained the institutional authorizations and performed the necessary ethical procedures.

\section{Population or sample; inclusion and exclusion criteria}

The participants were members of the AICU multiprofessional team. The total number of workers at the time of data collection was 62 , and the group was composed of 24 nursing technicians, 10 nurses, eight physicians, seven nursing assistants, four sanitation collaborators, four physiotherapists, two administrative assistants, one psychologist, one nutritionist and one technical support technician, that is, most of these workers (62.12\%) belonged to the nursing team.

The following criteria were used for the inclusion of participants: they should be members of the multidisciplinary team working at the hospital ICU; of both sexes; without distinction of shifts, profession/function exercised and work contracts; with training/ performance time in the institution and working at the AICU for over one year, due to need of the individual's labor experience ${ }^{(14)}$. Once these criteria were met, there was inclusion of 54 (87.09\% of the total) people.

\section{Study protocol}

For the collection of workers' information and obtainment of sociodemographic and occupational variables, there was employment of an instrument containing questions about age, sex, type of union, dependent children, occupation/function performed at the AICU, working hours, overtime in the last month prior to collection, performance of some other professional activity, and absence from work.

For the evaluation of presenteeism, the Stanford Presenteeism Scale (SPS-6), instrument validated in Brazil, was applied to evaluate labor productivity losses by means of two different dimensions. The first - Completing Work - relates to the physical causes of presenteeism, which correspond to the amount of work performed under the effect of the causes of this event. The second dimension - Avoiding Distraction - refers to the amount of concentration mobilized to produce when there is an effect of presenteeism ${ }^{(15)}$. 
Each of these factors is analyzed by three items, totaling six questions on a 5 -answer-option scale. SPS-6 score in dimension 2 uses reverse score, that is, it should consider the opposite value for the total score of presenteeism. For the individual evaluation of each dimension, the sum of the values should be used in a traditional way, without using the reverse score ${ }^{(15)}$.

The collection instruments were delivered in closed and unidentified envelopes to professionals who had interest, agreed upon participating in the research and signed the Informed Consent Forms (ICFs), which have been filled during the shifts but without disturbing the Unit functioning. In the end, the said author, who remained at the scene, collected the forms, taking care to note that there had been no communication between the workers on the issues of the instruments.

\section{Analysis of results and statistics}

The descriptive analysis was used for sociodemographic and occupational characterization; to evaluate the continuous variables, there was calculation of mean, standard deviation, median, and minimum and maximum; for the categorical variables, frequency and percentage were calculated. In order to relate presenteeism to sociodemographic and labor characteristics, tests were conducted for statistical average differences of the categorical variables (age, sex, civil union, dependent children, other professional activity, working schedule, overtime and absence from work), and the regression analyzes were performed. Mann-Whitney test and Kruskal-Wallis test of independent samples (used for statistical analyzes in which the data do not present normal distribution) were used, considering $a=0.05$.

\section{RESULTS}

Most of the 54 participants (42.6\%) were between 30 and 39 years old, presenting mean of 39.8 years; median age, 39 years; minimum and maximum ages of 25 and 62 years, respectively, and standard deviation (SD) of 9.0. These individuals were female $(75.9 \%)$, living in civil union (56.0\%), and reported having dependent children (53.7\%).

Regarding participants' occupational characteristics, the group gathered 23 (42.6\%) nursing technicians; 10 (18.5\%) nurses; six (11.1\%) physicians; four (7.3\%) physical therapists; three (5.6\%) nursing assistant; three (5.6\%) sanitation collaborators; two (3.7\%) administrative assistants; one (1.9\%) psychologist; one (1.9\%) technical support technician, and one (1.9\%) nutritionist; besides, it was evidenced that $66.7 \%$ participants were nursing professionals.

The work schedule with the highest number of participants $(18$, or $33.15 \%)$ was the 6 -hour day shift with a 12 -hour double shift. Twenty respondents (37\%) reported developing another professional activity in addition to that in the hospital, and 18 (90\%) among these worked in the health segment. Working overtime in the last six months was confirmed by 30 (55.6\%) participants, with an average of 38.23 hours/month; median of 36.0 ; minimum of 6.0 and maximum of 84 ; and SD of 17.12. Regarding absence from work, 29 (53.7\%) participants have not been away from work since they started the professional activities at the AICU.
Analyzing the results obtained with the use of the SPS-6, the following total presenteeism values were found: median, 16.5; mean, $14.8 ; S D, 6.8$; study range, $6-27$ points. The values found for median and mean of the total score were lower than 18 ; it is clear that values from 6 to 18 indicate a lower concentration capacity and reduction in performance at work, and high values in the total score, close to 30 , indicate greater concentration capacity and better performance at work, although the individual presents some health issues ${ }^{(15)}$.

The analysis of dimension 1 (Completing Work) is shown below (Table 1).

Table 2 shows the analysis of dimension 2 (Avoiding Distraction).

Table 3 below presents the values found in total presenteeism and its relation to sociodemographic and occupational/ labor variables.

Table 1 - Frequency of presenteeism in dimension 1- Completing Work - among the multiprofessional team workers of the Adult Intensive Care Unit, $2016(\mathrm{~N}=54)$

\begin{tabular}{ccc}
\hline SPS-6 Score* & $\boldsymbol{f}$ & $\%$ \\
\hline 3 & 17 & 31.8 \\
4 & 0 & 0 \\
5 & 0 & 0 \\
6 & 1 & 1.9 \\
7 & 0 & 0 \\
8 & 1 & 1.9 \\
9 & 4 & 7.3 \\
10 & 2 & 3.5 \\
11 & 9 & 17.0 \\
12 & 4 & 7.3 \\
13 & 5 & 9.0 \\
14 & 4 & 7.3 \\
15 & 7 & 13.0 \\
Total & 54 & 100.0 \\
\hline
\end{tabular}

Note: *Stanford Presenteeism Scale.

Table 2 - Frequency of Presenteeism in dimension 2 - Avoiding Distraction - among the multiprofessional team workers of the Adult Intensive Care Unit, $2016(\mathrm{~N}=54)$

\begin{tabular}{ccc}
\hline SPS-6 Score* & $\boldsymbol{f}$ & $\%$ \\
\hline 3 & 26 & 48.7 \\
4 & 2 & 3.5 \\
5 & 2 & 3.5 \\
6 & 5 & 9.0 \\
7 & 1 & 1.9 \\
8 & 5 & 9.5 \\
9 & 3 & 5.5 \\
10 & 6 & 11.0 \\
11 & 3 & 5.5 \\
12 & 0 & 0 \\
13 & 0 & 0 \\
14 & 0 & 0 \\
15 & 1 & 1.9 \\
Total & 54 & 100 \\
\hline
\end{tabular}

Note: *Stanford Presenteeism Scale. 
Table 3 - Distribution of values obtained according to the total presenteeism score and sociodemographic and occupational/labor variables of the multiprofessional team workers with activities at the Adult Intensive Care Unit

\begin{tabular}{|c|c|c|c|c|c|c|}
\hline Categorical Variables & $\mathbf{n}$ & $\begin{array}{l}\text { Presenteeism } \\
\text { Interval } \\
\text { obtained }\end{array}$ & Median & Mean & (SD) & $p$ value \\
\hline Age (years) & & & & & & $0.812^{*}$ \\
\hline $25-39$ & 27 & $6-27$ & 14.00 & 14.85 & 6.585 & \\
\hline $40-62$ & 27 & $0-26$ & 17.00 & 14.85 & 7.252 & \\
\hline Sex & & & & & & $0.021 *$ \\
\hline Male & 13 & $6-27$ & 19.00 & 18.69 & 5.360 & \\
\hline Female & 41 & $0-26$ & 14.00 & 13.63 & 6.888 & \\
\hline Civil Union & & & & & & $0.804^{*}$ \\
\hline No & 24 & $6-26$ & 16.50 & 15.08 & 7.003 & \\
\hline Yes & 30 & $6-27$ & 15.50 & 14.67 & 6.860 & \\
\hline Dependent Children & & & & & & $0.130^{*}$ \\
\hline No & 25 & $6-26$ & 14.00 & 13.20 & 7.489 & \\
\hline Yes & 29 & $6-27$ & 17.00 & 16.28 & 6.041 & \\
\hline Other professional activity & & & & & & $0.856^{*}$ \\
\hline No & 34 & $6-26$ & 15.00 & 14.65 & 6.897 & \\
\hline Yes & 20 & $6-27$ & 17.00 & 15.20 & 6.963 & \\
\hline Working Schedule & & & & & & $0.350 * *$ \\
\hline 8-hour fixed day shift & 11 & $6-23$ & 14.00 & 12.27 & 6.084 & \\
\hline 12-hour fixed night shift with 36 hours off & 14 & $6-26$ & 20.00 & 17.21 & 6.963 & \\
\hline 6-hour rotating day shift with 12 -hour double shift & 18 & $6-24$ & 16.50 & 14.83 & 6.724 & \\
\hline Rotating shift work & 11 & $6-27$ & 17.00 & 14.45 & 7.568 & \\
\hline Overtime & & & & & & $0.458 *$ \\
\hline No & 24 & $6-27$ & 14.00 & 14.08 & 7.009 & \\
\hline Yes & 30 & $6-26$ & 17.00 & 15.47 & 6.796 & \\
\hline Absence from work & & & & & & $0.040 *$ \\
\hline No & 29 & $6-23$ & 14.00 & 13.10 & 6.608 & \\
\hline Yes & 25 & $6-27$ & 17.00 & 16.88 & 6.710 & \\
\hline
\end{tabular}

Note: * Mann-Whitney test of independent samples ** Krushal-Wallis test of independent samples.

Mann-Whitney test was used for the analysis of variables age, sex, civil union, dependent children, other professional activity, overtime and absence from work; Kruskal-Wallis test was used for the analysis of the working schedule.

Analyzing the variable sex, it was possible to verify that men (13) presented the following: mean, 18.69; median, 19.00; SD, 5.360, and range, 6-27; in turn, women (41) presented mean, 13.63; median, $14.00 ; \mathrm{SD}, 6.888$, and range, $0-26$. $P$ value found in the analysis of this variable was 0.021 , demonstrating statistical significance.

The variable absence from work presented statistical significance $(p=0.040)$. The mean of those stating absence from work (25) was 16.88 , with median of 17.00; SD, 6.710, and range, 6-27. The mean of those who have declared no absence from work (29) was 13.10, with median of 14.00; SD, 6.608, and range, 6-23.

The values of dimension 1 and their relation with the participants' sociodemographic and occupational variables are presented below (Table 4).

Mann-Whitney and Kruskal-Wallis tests were chosen in order to perform the analyzes of the variables age, sex, civil union, dependent children, other professional activity, overtime and absence from work, both of independent samples.

Those who reported having dependent children presented higher values when compared with those who did not have them.
The values for the first (29) were: mean, 10.66; median, 11.00; SD, 4.64, and range, 3-15; among those who did not have children (25), the values were: mean of 7.40, median, 9.00; SD, 4.46; and range, 3-14. This variable presented statistical significance, with $p=0.008$.

Among those who reported having already been away from work, it was possible to verify higher values in relation to those who have not been absent from work. Among the first (25), the values were: mean, 10.52; median, 12.00; SD, 4.41; and range, 3-15; for those who have not been absent from work ( 29 workers), the values were: mean, 7.97; median, 9.00; SD, 4.51. The range for this group was 3-15, and this variable presented $p=0.026$, indicating statistical significance.

Table 5 shows the results obtained for the second dimension of SPS-6 (Avoiding Distraction).

The Mann-Whitney test was used to analyze the variables age, sex, civil union, dependent children, other professional activity, overtime and absence from work; Kruskal-Wallis test was used to analyze the working schedule; both tests of independent samples.

Analyzes made to identify differences in SPS-6 dimension 2 values and workers' sex showed that men (13) presented mean of 7.31; median, 8.00; SD, 3.664, and range, 3-15. Among women (41), the values were mean of 5.20; median, 3.00, SD, 2.909, and range, 3-11. Therefore, men presented higher values than women; the variable sex and SPS- 6 dimension 2 were statistically significant, with $p=0.043$. 
Table 4 - Distribution of values obtained according to the score of presenteeism dimension 1 (Completing Work) of the Stanford Presenteeism Scale (SPS-6), and sociodemographic and occupational/labor variables of the multiprofessional team workers with activities at the Adult Intensive Care Unit., 2016 ( $\mathrm{N}=54$ )

\begin{tabular}{|c|c|c|c|c|c|c|}
\hline \multirow[b]{2}{*}{ Categorical Variables } & \multirow[b]{2}{*}{$\mathbf{n}$} & \multicolumn{4}{|c|}{ Stanford Presenteeism Scale (SPS-6) dimension 1} & \multirow[b]{2}{*}{$p$ value } \\
\hline & & $\begin{array}{l}\text { Presenteeism } \\
\text { Interval obtained }\end{array}$ & Median & Mean & (SD) & \\
\hline Age (years) & & & & & & $0.902^{*}$ \\
\hline $25-39$ & 27 & $3-15$ & 11.00 & 9.22 & 4.432 & \\
\hline $40-62$ & 27 & $3-15$ & 11.00 & 9.07 & 4.867 & \\
\hline Sex & & & & & & $0.066^{*}$ \\
\hline Male & 13 & $3-15$ & 12.00 & 11.38 & 3.124 & \\
\hline Female & 41 & $3-15$ & 10.00 & 8.44 & 4.806 & \\
\hline Civil Union & & & & & & $0.838^{*}$ \\
\hline No & 24 & $3-15$ & 10.50 & 9.04 & 4.667 & \\
\hline Yes & 30 & $3-15$ & 11.00 & 9.23 & 4.644 & \\
\hline Dependent Children & & & & & & $0.008^{*}$ \\
\hline No & 25 & $3-14$ & 9.00 & 7.40 & 4.463 & \\
\hline Yes & 29 & $3-15$ & 11.00 & 10.66 & 4.253 & \\
\hline Other professional activity & & & & & & $0.913^{*}$ \\
\hline No & 34 & $3-15$ & 10.50 & 9.06 & 4.735 & \\
\hline Yes & 20 & $3-15$ & 11.00 & 9.30 & 4.508 & \\
\hline Working Schedule & & & & & & $0.314^{* *}$ \\
\hline 8-hour fixed day shift & 11 & $3-13$ & 11.00 & 8.09 & 4.437 & \\
\hline 12-hour fixed night shift with 36 hours off & 14 & $3-15$ & 11.50 & 10.79 & 4.560 & \\
\hline 6-hour rotating day shift with 12 -hour double shift & 18 & $3-15$ & 10.50 & 9.17 & 4.842 & \\
\hline Rotating shift work & 11 & $3-14$ & 9.00 & 8.09 & 4.460 & \\
\hline Overtime & & & & & & $0.703^{*}$ \\
\hline No & 24 & $3-15$ & 11.00 & 8.83 & 4.706 & \\
\hline Yes & 30 & $3-15$ & 11.00 & 9.40 & 4.598 & \\
\hline Absence from work & & & & & & $0.026^{*}$ \\
\hline No & 29 & $3-15$ & 9.00 & 7.97 & 4.516 & \\
\hline Yes & 25 & $3-15$ & 12.00 & 10.52 & 4.417 & \\
\hline
\end{tabular}

Note: * Mann-Whitney test of independent samples ** Krushal-Wallis test of independent samples.

Table 5 - Distribution of values obtained according to the score of presenteeism dimension 2 (Avoiding Abstraction) of the Stanford Presenteeism Scale (SPS-6) and sociodemographic and occupational/labor variables of the multiprofessional team workers with activities at the Adult Intensive Care Unit., 2016 ( $\mathrm{N=54)}$

\begin{tabular}{|c|c|c|c|c|c|c|}
\hline \multirow[b]{2}{*}{ Categorical Variables } & \multicolumn{5}{|c|}{ Stanford Presenteeism Scale (SPS-6) dimension 2} & \multirow[b]{2}{*}{$p$ value } \\
\hline & $\mathbf{n}$ & $\begin{array}{c}\text { Presenteeism } \\
\text { Interval obtained }\end{array}$ & Median & Mean & (SD) & \\
\hline Age (years) & & & & & & $0.811^{*}$ \\
\hline $25-39$ & 27 & $3-15$ & 4.00 & 5.63 & 3.330 & \\
\hline $40-62$ & 27 & $3-11$ & 4.00 & 5.78 & 3.105 & \\
\hline Sex & & & & & & $0.043^{*}$ \\
\hline Male & 13 & $3-15$ & 8.00 & 7.31 & 3.614 & \\
\hline Female & 41 & 3-11 & 3.00 & 5.20 & 2.909 & \\
\hline Civil Union & & & & & & $0.283^{*}$ \\
\hline No & 24 & 3-11 & 5.50 & 6.04 & 3.043 & \\
\hline Yes & 30 & $3-15$ & 3.00 & 5.43 & 3.329 & \\
\hline Dependent Children & & & & & & $0.927^{*}$ \\
\hline No & 25 & $3-15$ & 3.00 & 5.80 & 3.559 & \\
\hline Yes & 29 & $3-11$ & 4.00 & 5.62 & 2.896 & \\
\hline Performance of other professional activity & & & & & & $0.827^{*}$ \\
\hline No & 34 & $3-11$ & 4.00 & 5.59 & 3.046 & \\
\hline Yes & 20 & 3-15 & 4.00 & 5.90 & 3.493 & \\
\hline
\end{tabular}




\begin{tabular}{|c|c|c|c|c|c|c|}
\hline \multirow[b]{2}{*}{ Categorical Variables } & \multicolumn{5}{|c|}{ Stanford Presenteeism Scale (SPS-6) dimension 2} & \multirow[b]{2}{*}{$p$ value } \\
\hline & $\mathbf{n}$ & $\begin{array}{c}\text { Presenteeism } \\
\text { Interval obtained }\end{array}$ & Median & Mean & (SD) & \\
\hline Working Schedule & & & & & & $0.282^{* *}$ \\
\hline 8-hour fixed day shift & 11 & $3-10$ & 3.00 & 4.18 & 2.272 & \\
\hline 12-hour fixed night shift with 36 hours off & 14 & $3-11$ & 6.50 & 6.43 & 3.251 & \\
\hline 6-hour rotating day shift with 12 -hour double shift & 18 & $3-11$ & 5.50 & 5.67 & 2.808 & \\
\hline Rotating shift work & 11 & $3-15$ & 3.00 & 6.36 & 4.225 & \\
\hline Overtime & & & & & & $0.233^{*}$ \\
\hline No & 24 & $3-15$ & 3.00 & 5.25 & 3.442 & \\
\hline Yes & 30 & $3-11$ & 6.00 & 6.07 & 2.982 & \\
\hline Absence from work & & & & & & $0.138^{*}$ \\
\hline No & 29 & $3-11$ & 3.00 & 5.14 & 2.887 & \\
\hline Yes & 25 & 3-15 & 6.00 & 6.36 & 3.451 & \\
\hline
\end{tabular}

Nota: *Teste de Mann-Whitney de amostras independentes ${ }^{* *}$ Teste de Kruskal-Wallis de amostras independentes.

\section{DISCUSSION}

Workers who carry out their activities, especially in hospitals, coexist with complex and stressful scenarios ${ }^{(16)}$. ICUs are places of care for patients in critical states with variations in prognosis; therefore, those who work in these places experience situations of patients' life and death, which may result in emotional vulnerability, anxiety, guilt and impotence ${ }^{(17)}$.

In this study, $85.2 \%$ respondents were younger than 49 years old, indicating a population of still relatively young adults. A Korean study demonstrated the relationship between age and the prevalence of pathologies in workers' joints; older individuals are more likely to develop this type of pathologies ${ }^{(18)}$, which possibly end up hampering their work.

Most of the workers were women, and belonging to the nursing team (66.7\%). In health services, the presence of female labor is expressive ${ }^{(19-20)}$; at the ICU, the presence of the nursing team is fundamental, since it is a place where patients are at imminent risk of death, are highly dependent, and require complex care ${ }^{(21)}$.

Among the workers, 56\% affirmed to live in civil union; these unions are those in which people live in a consensual lasting relationship, established for the purpose of family constitution, without the need for a marriage certificate in the notary's office ${ }^{(22)}$. The presence of dependent children was confirmed by $53.7 \%$ respondents. If the individuals have children, in addition to their working hours, they may still develop household activities and care to offspring, which results in work double/triple shifts, especially for women ${ }^{(23)}$.

The professionals that worked at the AICU faced different amount of working hours due to their types of contractual ties. The amount of working hours is an essential element in worker's life; working hours should be established in rules or legislation which prioritize workers' safety and health by ensuring that they are not exposed to excessive working hours, besides enjoyment of rest periods and vacation ${ }^{(24)}$. Excessive working hours may lead to physical and mental exhaustion, which may result in psychological and physical changes ${ }^{(25)}$.

In this study, 55.6\% participants performed overtime in the month prior to data collection. When the individual faces long working days, performs excessive overtime, or has a double employment relationship, the person may have his/her quality of life influenced negatively and submit to the highest levels of occupational stress ${ }^{(19,26)}$. Overtime may lead to excessive workload, which may favor the occurrence of adverse events ${ }^{(27-28)}$.

With regard to absence from work, 53.7\% participants have not been absent since they began their professional activities at the AICU. Ways of working may result in physical and mental exhaustion, capable of provoking accidents and illnesses in workers. Sick leave is related to work accidents, several physical problems, as well as suffering and mental illness ${ }^{(29)}$.

Presenteeism is commonly found in healthcare professionals; musculoskeletal pain may be responsible for decreased work performance, and may cause difficulty in making the movements necessary for the exercise of the function ${ }^{(30)}$. Changes in physical and mental health, reduced ability to work and occurrence of presenteeism are likely to occur due to the organizational context of the workplace and the relationships between teams ${ }^{(31)}$. Workers with greater sense of well-being are less absent from work, reduce presenteeism and show the intention to remain in their work stations ${ }^{(32)}$.

Productivity consists of carrying out activities during working hours; it is the relationship between the results of production and the productive resources applied to $\mathrm{it}^{(33)}$. Work productivity reduction may be related to depression, anxiety, financial issues, increased workloads and health issues. It is important to investigate the presenteeism among workers, since they reduce their productivity but are not absent from their work stations, causing this phenomenon ${ }^{(34)}$.

In the statistical analyzes of this study, differences with statistical significance were found: in the general SPS-6 score, for the variables sex and absence from work; in dimension 1, for the variables having dependent children and absence from work; and in dimension 2 for the variable sex.

Regarding the assessments of the two dimensions of this scale, in the first dimension (Completing Work), the score three among 17 workers (31.8\%) was found, considering that in this dimension the lower the score, the greater the difficulties for the worker to finish his/her activities, indicating how much the health condition may interfere with the accomplishment and completion of the tasks at work; it should be noted that they account for about one-third of 
respondents. Regarding dimension 2 (Avoiding Distraction), most of the values found were for score three $(48.7 \%)$, considering that the higher the score, the lower the concentration of the individual at work, indicating greater impairment of concentration, and that lower values indicate a better psychological state ${ }^{(15)}$, there being lower impairment in this dimension

Stress experienced at work is capable of influencing the occurrence of presenteeism among workers; the support from colleagues can ease this stress and, consequently, the presence of this phenomenon, as proven in an American research ${ }^{(35)}$. A Polish study has shown that costs associated with its occurrence can exceed two to five times the expenses incurred with absenteeism, when comparing both ${ }^{(36)}$.

The occurrence of presenteeism may result in generation of high costs for the institutions, since it is a phenomenon of difficult evaluation and measurement. Because of the increase of costs that it may represent, its investigation is essential, since it is possible to formulate strategies and means to mitigate its occurrence $^{(37)}$ by knowing it better. It is a phenomenon that may result in financial losses for institutions and organizations; however, it is important to consider it not only because of the financial impact and its consequences, but also due to its psychosocial relevance ${ }^{(38)}$.

Workers with chronic diseases are more likely to present presenteeism than healthy workers ${ }^{(39)}$; individual characteristics such as affect, motivation, commitment and engagement in activities can influence the decision of the worker to go to work even when ill(38). Psychological support can prevent mental disorders from becoming chronic by early identification of changes that may compromise them. Such interventions are capable of reducing presenteeism, absenteeism, absence from work, sick leave and costs to the employer ${ }^{(40)}$.

\section{Study limitations}

This study had limitations because it was performed at a single AICU; larger number of respondents may make it possible to find more values of statistical significance.

\section{Contributions to nursing and health areas or public policies}

The study advances in knowledge since it evaluated presenteeism regarding the multiprofessional team that works at this type of complex Unit. It is expected that the results may contribute to workers' health, since presenteeism may result from damages and physical and psychological health issues among them.

\section{CONCLUSION}

In the evaluated AICU, expressive presenteeism numbers have been verified in the general evaluation. By evaluating the SPS- 6 different dimensions, with regard to the first one, the results found indicated impairment in completing work, and in the second dimension, it was possible to identify better psychological state among the multiprofessional team workers. When relating presenteeism results to sociodemographic and labor characteristics, the variables sex, having dependent children and absence from work presented values with statistical significance among the multiprofessional team workers studied.

\section{REFERENCES}

1. Schmoeller R, Trindade Lde L, Neis MB, Gelbcke FL, de Pires DE. [Nursing workloads and working conditions: integrative review]. Rev Gaucha Enferm [Internet]. 2011 [cited 2017 Jan 5];32(2):368-77. Available from: http://dx.doi.org/10.1590/S1983-14472011000200022. Portuguese.

2. Ribeiro G, Pires DEP, Scherer MD dos A, Biosecurity practices in technical nursing education. Trab. Educ. Saúde [Internet]. 2016 [cited 2017 Jan 5];14(3):871-88. Available from: http://dx.doi.org/10.1590/1981-7746-sol00019

3. Santana L de L, Sarquis LMM, Miranda FMD, Kalinke LP, Felli VEA, Mininel VA, et al. Health indicators of workers of the hospital area. Rev Bras Enferm [Internet]. 2016 [cited 2016 Apr 4];69(1):30-9. Available from: http://dx.doi.org/10.1590/0034-7167.2016690104i

4. Pêgo FPL e, Pêgo DR. Síndrome de Burnout. Rev Bras Med Trab. 2016;14(2):171-6. doi:10.5327/Z1679-443520162215.

5. Ministério da Saúde (BR), Agência Nacional de Vigilância Sanitária (ANVISA). Resolução n. 7, de 24 de fevereiro de 2010. Dispõe sobre os requisitos mínimos para funcionamento de Unidades de Terapia Intensiva e dá outras providências [Internet]. Diário Oficial da União: República Federativa do Brasil; 2010 [cited 2018 Sep 23]. Available from: http://bvsms.saude.gov.br/bvs/saudelegis/anvisa/2010/res0007_24_02_2010.html

6. Proença MO, Agnolo CMD. [Hospitalization in the intensive care unit: overview of patients who experienced]. Rev Gaúcha Enferm [Internet]. 2011 [cited 2015 Apr 29];32(2):279-86. Available from: http://dx.doi.org/10.1590/S1983-14472011000200010 Portuguese

7. Moon JY, Kim J-O. Ethics in the Intensive Care Unit. Tuberc Respir Dis. 2015;78(3):175-9. doi: 10.4046/trd.2015.78.3.175

8. Shimizu HE, Ciampone MHT. [The representations of nursing auxiliaries and technicians about team work at an Intensive-Care Unit]. Rev Lat Am Enfermagem [Internet]. 2004 [cited 2017 Aug 13];12(4):623-30. Available from: http://dx.doi.org/10.1590/S0104-11692004000400007 Portuguese.

9. Teston S de F, Grigol C. Fatores de estresse e a sustentabilidade social em uma empresa do ramo da saúde de Chapecó. InterfacEHS [Internet]. 2015 [cited 2016 Apr 9];9(2). Available from: http://www.revistas.sp.senac.br/index.php/ITF/article/view/665

10. Bubonya M, Cobb-Clark DA, Wooden M. Mental Health and Productivity at Work: Does What You Do Matter? LabourEcon [Internet]. 2017 [cited 2017 May 10]; Available from: https://doi.org/10.1016/j.labeco.2017.05.001

11. Kamiri L, Cheng C, Bartram T, Leggat SG, Sarkeshik S. The effects of emotional intelligence and stress-related presenteeism on nurses' wellbeing. Asia Pac J Hum Resourc. 2015;53(3):296-310. doi:10.1111/1744-7941.12049 
12. Krane L, Larsen EL, Nielsen CV, Stapelfeldt CM, Johnsen R, Risør MB. Attitudes towards sickness absence and sickness presenteeism in health and care sectors in Norway and Denmark: a qualitative study. BMC Public Health. 2014;14:880. doi: 10.1186/1471-2458-14-880

13. Veale PM, Vayalumkal JV, McLaughlin K. Sickness presenteeism in clinical clerks: Negatively reinforced behavior or an issue of patient safety? Am J Infect Control. 2016;44(8):892-7. doi: 10.1016/j.ajic.2016.01.043

14. Viero CM, Camponogara S, Cezar-Vaz MR, Costa VZ da, Beck CLC. Risk society: the use of pesticides and implications for the health of rural workers. Esc Anna Nery [Internet]. 2016 [cited 2016 May 4];20(1):99-105. Available from: http://dx.doi.org/10.5935/1414-8145.20160014

15. Paschoalin HC, Griep RH, Lisboa MTL, de Mello DCB. Transcultural adaptation and validation of the Stanford Presenteeism Scale for the evaluation of presenteeism for Brazilian Portuguese. Rev Lat Am Enfermagem [Internet]. 2013 [cited 2017 May 4];21(1):388-95. Available from: https://doi.org/10.1590/S0104-11692013000100014

16. Jones G, Hocine M, Salomon J, Dab W, Temime L. Demographic and occupational predictors of stress and fatigue in French intensive-care registered nurses and nurses' aides: A cross-sectional study. Int J Nurs Stud. 2015;52(1):250-9. doi: 10.1016/j.ijnurstu.2014.07.015

17. Jansen K, Ruths S, Malterud K, Schaufel MA. The impact of existential vulnerability for nursing home doctors in end-of-life care: A focus group study. Patient Educ Couns. 2016;99(12):2043-88. doi: 10.1016/j.pec.2016.07.016.

18. Seok H, Choi SJ, Yoon J-H, Song GG, Won JU, Kim JH. The association between osteoarthritis and occupational clusters in the korean population: a nationwide study. PLoS One. 2017;12(1):e0170229. doi: 10.1371/journal.pone.0170229.

19. Palhares Vde C, Corrente JE, Matsubara BB. Association between sleep quality and quality of life in nursing professionals working rotating shifts. Rev Saúde Pública [Internet]. 2014 [cited 2017 Jan 25];48(4):594-601. Available from: https://doi.org/10.1590/ S0034-8910.2014048004939

20. Jager N, Nolte AGW, Temane A. Strategies to facilitate professional development of the occupational health nurse in the occupational health setting. Health SA Gesondheid [Internet]. 2016 [cited 2017 May 10];21:261-70. Available from: https://doi.org/10.1016/j.hsag.2016.03.003

21. Inoue KC, Matsuda LM. The extent of the adult-ICU nursing crew in a school hospital. Rev Eletr Enf [Internet]. 2009 [cited 2017 Aug 13];11(1):55-63. Available from: http://www.fen.ufg.br/revista/v11/n1/v11n1a07.htm

22. Covre SM. Socioeconomic and cultural features of consensual unions in Brazil. Rev Bras Estud Popul [Internet]. 2016 [cited 2017 Apr 3];33(1):53-74. Available from: http://dx.doi.org/10.20947/S0102-309820160004

23. Silva KN, Dutra FCMS, Silva KN, Dutra FCMS. Psychosocial job factors and chronic pain: analysis in two municipal schools in Serrana/SP. Rev Dor. 2016;17(3):164-70. doi: 10.5935/1806-0013.20160064

24. Cabrita J, Boehmer S, Galli da Bino C. Working time developments in the 21st century: work duration and its regulation in the EU [Internet]. Dublin (IE): EUROFOUND; c2016 [cited 2018 Sep 23]. 102 p. Available from: https://www.eurofound.europa.eu/sites/default/files/ef_ publication/field_ef_document/ef1573en.pdf

25. Sponholz TCH, Sartori MT, Marques APS, Albuquerque GSC, Silva MJS e, Perna PO, et al. [Workprocess in medical residency: the subordination of teaching and learning to the exploitation of the resident work force]. Trab Educ Saúde [Internet].2016 [cited 2017 Jan 25];14:67-87. Available from: http://dx.doi.org/10.1590/1981-7746-sol00025 Portuguese.

26. Ganime JF, Almeida Silva L, Robazzi MC, ValenzuelaSauzo S, Faleiro SA. O ruído como um dos riscos ocupacionais : uma revisão de literatura. Enferm Glob [Internet]. 2010 [cited 2017 May 10];(19):0-0. Available from: http://scielo.isciii.es/scielo.php?script=sci_arttext\&pid $=$ S1695-61412010002200220

27. Quadros DV, Magalhães AM, Mantovani VM, Rosa DS, Echer IC. Analysis of managerial and healthcare indicators after nursing personnel upsizing. Rev Bras Enferm [Internet]. 2016 [cited 2017 Feb 24];69(4):684-90.Available from: http://dx.doi. org/10.1590/0034-7167.2016690410i.

28. Curan GRF, Beraldo A, Souza SNDH, Rossetto EG. [Sizing of Staff of Neonatal Units in a University Hospital]. Semina Ciênc Biol Saúde [Internet]. 2015 [cited 2017 Feb 24];36(1Supl):55-62. Available from: http://dx.doi.org/10.5433/1679-0367.2015v36n1Suplp55 Portuguese.

29. Scherer MD A, Oliveira NA, Pires DEP, Trindade LL, Gonçalves ASR, Vieira M, et al. [Increased workloads for nurse technicians in primary healthcare in Brazil]. Trab Educ Saúde [Internet]. 2016 [cited 2017 Feb 23];14(supl1):89-104. Available from: http://dx.doi.org/10.1590/19817746-sol00030. Portuguese.

30. Dhaini SR, Zúñiga F, Ausserhofer D, Simon M, Kunz R, De Geest S, Schwendimann R. Are nursing home care workers' health and presenteeism associated with implicit rationing of care? A cross-sectional multi-site study. Geriatr Nurs. 2017;38(1):33-38. doi: 10.1016/j. gerinurse.2016.07.003

31. Schulz H, Zacher H, Lippke S. The importance of team health climate for health-related outcomes of white-collar workers. Front Psychol. 2017;8:74. doi: 10.3389/fpsyg.2017.00074

32. Sears LE, Shi Y, Coberley CR, Pope JE. Overall well-being as a predictor of health care, productivity, and retention outcomes in a large employer. Popul Health Manag [Internet]. 2013 [cited 2017 Feb 26];16(6):397-405. Available from: doi: 10.1089/pop.2012.0114

33. Barbosa FH, Pessôa SA. Pessoal ocupado e jornada de trabalho: uma releitura da evolução da produtividade no Brasil. Rev Bras Econ [Internet]. 2014 [cited 2017 Apr 25];68(2):149-69. Available from: http://dx.doi.org/10.1590/S0034-71402014000200001.

34. Mazanec SR, Daly BJ, Douglas SL, Lipson AR. Work Productivity and Health of Informal Care givers of Persons With Advanced Cancer. Res Nurs Health. 2011;34(6):483-95. doi: 10.1002/nur.20461 
35. Yang T, Shen YM, Zhu M, Liu Y, Deng J, Chen Q, See LC. Effects of co-worker and supervisor support on job stress and presenteeism in an aging workforce: a structural equation modelling approach. Int J Environ Res Public Health. 2015;13(1):ijerph13010072. doi: 10.3390/ ijerph13010072.

36. Pęciłło M. Selected aspects of absence at work and work-related health problems in Polish enterprises. Int J Occup Saf Ergon.2015;21(3):268-75. doi: 10.1080/10803548.2015.1081768.

37. Kigozi J, Jowett S, Lewis M, Barton P, Coast J. The estimation and inclusion of presenteeism costs in applied economic evaluation: a systematic review. Value Health [Internet]. 2017 [cited 2017 Mar 22];20(3):496-506. Available from: doi: 10.1016/j.jval.2016.12.006

38. Karanika-Murray M, Pontes HM, Griffiths MD, Biron C. Sickness presenteeism determines job satisfaction via affective-motivational states. Soc Sci Med. 2015;139:100-6. doi: 10.1016/j.socscimed.2015.06.035

39. Skagen K, Collins AM. The consequences of sickness presenteeism on health and wellbeing over time: a systematic review. Soc Sci Med. 2016;161:169-77. doi: 10.1016/j.socscimed.2016.06.005

40. Preiser C, Rothermund E, Wittich A, Gündel H, Rieger MA. Psychosomatic consultation in the workplace: opportunities and limitations of the services offered--results of a qualitative study. Int Arch Occup Environ Health [Internet]. 2016 [cited 2017 Feb 26];89(4):599-608. Available from: doi: 10.1007/s00420-015-1098-y 